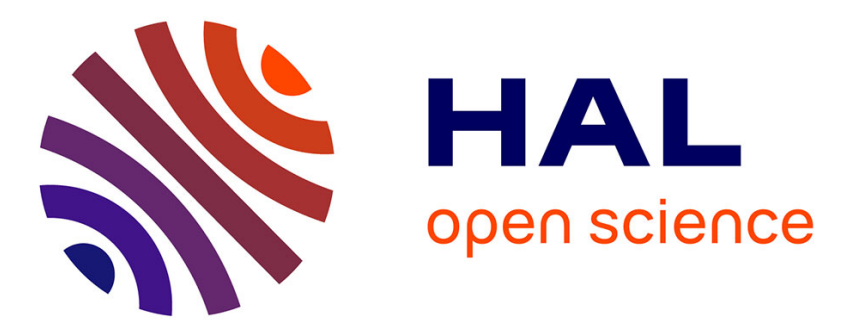

\title{
Calcific tendonitis of the rotator cuff: From formation to resorption
}

\author{
Christelle Darrieutort-Laffite, Frédéric Blanchard, Benoît Le Goff
}

\section{To cite this version:}

Christelle Darrieutort-Laffite, Frédéric Blanchard, Benoît Le Goff. Calcific tendonitis of the rotator cuff: From formation to resorption. Joint Bone Spine, 2017, Epub ahead of print. 10.1016/j.jbspin.2017.10.004 . inserm-01668539

\section{HAL Id: inserm-01668539 https://www.hal.inserm.fr/inserm-01668539}

Submitted on 20 Dec 2017

HAL is a multi-disciplinary open access archive for the deposit and dissemination of scientific research documents, whether they are published or not. The documents may come from teaching and research institutions in France or abroad, or from public or private research centers.
L'archive ouverte pluridisciplinaire HAL, est destinée au dépôt et à la diffusion de documents scientifiques de niveau recherche, publiés ou non, émanant des établissements d'enseignement et de recherche français ou étrangers, des laboratoires publics ou privés. 


\section{Accepted Manuscript}

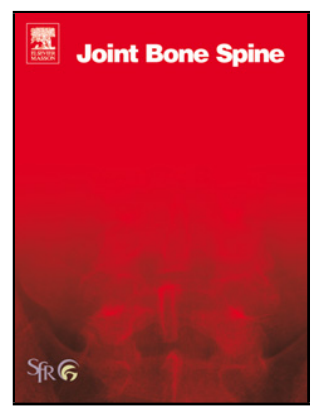

Title: Calcific tendonitis of the rotator cuff: from formation to resorption

Author: Christelle Darrieutort-Laffite Frédéric Blanchard Benoit Le Goff S1297-319X(17)30194-X

PII: https://doi.org/doi:10.1016/j.jbspin.2017.10.004

DOI: BONSOI 4650

To appear in:

Received date: $\quad 4-8-2017$

Accepted date: $\quad$ 19-10-2017

Please cite this article as: Darrieutort-Laffite C, Blanchard F, Le Goff B, Calcific tendonitis of the rotator cuff: from formation to resorption, Joint Bone Spine (2017), https://doi.org/10.1016/j.jbspin.2017.10.004

This is a PDF file of an unedited manuscript that has been accepted for publication. As a service to our customers we are providing this early version of the manuscript. The manuscript will undergo copyediting, typesetting, and review of the resulting proof before it is published in its final form. Please note that during the production process errors may be discovered which could affect the content, and all legal disclaimers that apply to the journal pertain. 
Calcific tendonitis of the rotator cuff: from formation to resorption

Christelle Darrieutort-Laffite $^{1,2}$, Frédéric Blanchard ${ }^{2}$, Benoit Le Goff ${ }^{1,2}$

${ }^{1}$ Department of Rheumatology, Nantes University Hospital, 44093 Nantes, France

2 INSERM U1238. PHY-Os, Bone Sarcomas and remodeling of calcified tissues, University of Nantes School of Medicine, 44093 Nantes, France

Christelle Darrieutort-Laffite (Corresponding author)

Service de Rhumatologie, CHU Nantes, 1 place Alexis Ricordeau, 44093 Nantes Cedex 1, France

Tel : +33240084801

E-mail : christelle.darrieutort@chu-nantes.fr 


\section{ABSTRACT:}

Calcific tendonitis of the rotator cuff is due to apatite deposits in the shoulder tendons. Patients affected by calcific tendonitis have chronic shoulder pain and disability. Although the disease is frequent, about 10 to $42 \%$ of painful shoulders, mechanisms leading to this pathological mineralization are still largely unknown.

Research reported in the 90s suggested that the formation of calcific deposits is linked to cells looking like chondrocytes identified around calcium deposits within a fibrocartilage area. They were considered to be derived from tenocytes but more recently, tendon stem cells, able to differentiate into chondrocytes, were isolated. The pro-mineralizing properties of these chondrocytes-like cells, especially the role of alkaline phosphatase, are not currently clarified. The calcium deposits contain poorly crystalline carbonated apatite associated with protein. Among these proteins, only osteopontin has been consistently identified as a potential regulating factor. During the disease, spontaneous resorption can occur with migration of apatite crystals into the subacromial bursa causing severe pain and restriction of movement. In in vivo and in vitro experiments, apatite crystals were able to induce an influx of leucocytes and a release of IL-1 $\beta$ and IL-18 through the activation of the NLRP3 inflammasome. However, mechanisms leading to spontaneous resolution of this inflammation and disappearance of the calcification still need to be elucidated.

Keywords: calcific tendonitis, shoulder, apatite 


\section{Introduction}

Calcific tendonitis (CT) is one of the most frequent causes of non-traumatic shoulder pain. CT is found in 10 to $42 \%$ of chronic painful shoulders [1-4]. Calcific deposits can also remain asymptomatic, found in $3 \%$ of nonpainful shoulders [5]. Patients suffering from CT are generally aged between 30 and 60 years and women are more often affected than men. Bilateral involvement is common and CT is not linked to manual work [6]. Calcium deposits are more often located in the supraspinatus tendon. Factors associated with the development of symptoms are still unclear although the size and presence of a bursitis on imaging have been shown to be associated with the pain [7]. Calcium deposits may result in chronic pain with discomfort during daily and professional activities. During the evolution, an acute inflammatory episode may occur, leading to the disappearance of the calcification. Although frequent, the mechanisms leading to the deposition of calcium crystals within the tendon remain unclear. Moreover, factors associated with its spontaneous resorption are also unknown.

In this review, we will first discuss the data available on the mechanisms and cells involved in the formation of the calcium deposits. We will next analyze the different steps associated with their disappearance.

\section{Calcific deposits formation}

The hypothesis most frequently accepted was proposed by Uhthoff et al. [8] who considered that the mineralization process starts with a metaplasia of tenocytes into chondrocytes and that the deposition is actively mediated by these chondrocyte-like cells.

\subsection{Cells involved in the formation of the calcium deposits}

Normal tendons are composed of collagen, elastic fibers and a ground substance. The main component of tendons is type I collagen, which accounts for approximately $60-85 \%$ of the dry weight of the tendons. The remaining ground substance acts like anhydrophilic gel which surrounds the collagen. It contains proteoglycans, glycosaminoglycans (GAGs), structural glycoproteins, and a wide variety of inorganic components (calcium, 
magnesium, manganese, copper, zinc, phosphore...) [9]. These elements are produced by tenocytes, which are elongated fibroblast-like cells that lie between the collagen fibers.

Calcific tendonitis is characterized by the presence of calcium deposits which appear as amorphous areas located within the tendon fibers (Figure 1). Several studies have described the presence of chondrocyte-like cells surrounding these deposits $[8 ; 10 ; 11]$. They have a rounded morphology and are located in lacuna as chondrocytes in the cartilage. The matrix surrounding these cells become metachromatic (toluidine blue and Azur A positive staining), suggesting a fibrocartilaginous composition (GAGs). It also contains chondroitin-4sulphate and chondroitin-6-sulphate, especially around the cells [11]. The lack of type II collagen [11; 12] suggests that this "fibrocartilaginous area" differs from other forms of fibrocartilage. Few patients were reported to have an osseous metaplasia near the calcium deposit but this pattern seems rare and probably does not represent the main mechanism involved $[8 ; 11]$.

Uhthoff et al. assumed that the presence of chondrocyte-like cells in the tendon was explained by a metaplasia of tenocytes into chondrocytes [8; 12]. Factors able to drive this metaplasia are still unknown. Extracellular matrix of the tendon can be modified in response to load with formation of a fibrocartilaginous matrix at sites where the tendons are under compression [13]. This compression could occur when the supraspinatus tendon become impinged under the subacromial space during overhead activities. In line with this hypothesis, genes that are highly expressed in fibrocartilage (type II collagen and aggrecan) or in cartilage tissue (Sox9) are upregulated in the overused supraspinatus tendon [14]. Chondroid cells have also been observed within degenerative tendinous lesions [15]. However, overuse and degenerative phenomenon cannot be the only factors involved as CT is usually observed in young patients and is not associated with manual work.

Another hypothesis could be that these chondrocyte-like cells derive from mesenchymal stem cells. Several studies have demonstrated the existence of stem cells within the tendons (TSCs) [16]. TSCs are characterized by their multidifferentiation potential and are able to differentiate into adipocytes, chondrocytes, and osteocytes in vitro, and form tendon-like, cartilage-like, and bone-like tissues in vivo [17]. The hypothesis that TSCs might be able to drive the chondrocyte transformation in the tendon remains to be explored.

\subsection{Cellular mechanisms involved in the mineralization process}


Mineralization is an active and complex process involving protein and enzymes leading to crystal deposition. Matrix vesicles (MVs) are essential in the formation of cartilage, bone and dentin. These nano-vesicular structures, found in the extracellular matrix, are one of the sites of mineral nucleation that occurs in the organic matrix of the tissues. MVs are enriched in tissue nonspecific alkaline phosphatase (TNAP), phosphatidylserine, nucleotide pyrophosphatase phosphodiesterase 1 (NPP1) and Phospho- $1 . \mathrm{Ca}^{2+}$ and $\mathrm{PO}_{4}{ }^{3-}$ in the extracellular matrix are transported into MVs via MV transporters, annexins for $\mathrm{Ca}^{2+}$ and $\mathrm{Pit}-1 / 2$ for $\mathrm{PO}_{4}{ }^{3-}$. Within $\mathrm{MV}$, the ions interact with membrane phospholipids to form a nucleational core complex, resulting in the formation of nanocrystals [18]. In 1993, Archer et al. found that matrix vesicles were present in tendons but without any difference in their distribution between foci of calcification and normal tendon [11]. Uhthoff et al. found an intracellular activity of alkaline phosphatase in chondrocyte-like cells and in the matrix surrounding the cells (Gomori staining). They suggested that the coalescence of calcium crystals present in matrix vesicles (MVs) could form the calcification and considered the phenomenon as an incomplete endochondral ossification [8]. On the opposite, Archer at al. did not detect alkaline phosphatase enzymatic activity in areas containing the distinctive rounded cells. For them, the lack of collagen type II and alkaline phosphatase in the pathological regions suggests that the calcification process is not mediated through an endochondral transition [11].

Others data suggest a crucial role of phospholipids released by cellular debris in pathological calcifications. Indeed, studying various pathological calcifications (fibrocartilage, kidney stones, tendon, skin and arteries), Boskey et al. observed a high Ca-PL-P complexes content (calcium acidic phospholipid phosphate) in tissues containing hydroxyapatite [19]. These complexes are able to induce both in vitro and in vivo hydroxyapatite deposition $[19,20]$. The presence of these Ca-PL-P complexes indicates the presence of cellular and membrane debris in the deposits. In calcium pyrophosphate deposition (CPPD) disease, CPPD crystals are known to cause cell lysis which can produce membrane debris able to provide sites for new crystal formation. Such a mechanism could be involved in the formation or the growth of apatite deposits.

Overall, chondrocyte-like cells have clearly been identified around calcifications and probably have a critical role in the calcification process. However, cellular mechanisms involved in the deposition of apatite crystals are not well established. Discrepancies exist about their ability to produce mineralizing enzymes such as alkaline phosphatase. The characterization of the mineral composition of the calcific deposits could be helpful to better understand these mechanisms. 


\subsection{Mineral composition of the calcific deposits}

Analyses of the calcific deposits aspirated during US-guided lavage allow the characterization of their crystalline composition. Scanning electron microscopy shows a powder with organic matter and a poorly crystalline phase containing ellipsoidal objects of sizes ranging from $5 \mu \mathrm{m}$ to $200 \mu \mathrm{m}$ in diameter [21]. X-ray diffraction (XRD) shows poorly crystalline carbonated apatite with broader peaks than the synthetic hydroxyapatite (HAP) [22; 23]. These samples are characterized by a Ca:P molar ratio about 1,7 , close to the one observed in hydroxyapatite $(1,67)$. With Fourier transform infrared spectroscopy (FTIR), two types of carbonates apatite have been identified: type $\mathrm{A}$ and type $\mathrm{B}$ according to the position of ion $\mathrm{CO}_{3}{ }^{2-}[21]$. The main difference with synthetic HAP is the absence of $\mathrm{OH}^{-}$band and the presence of $\mathrm{CO}_{3}$ groups in bands at 870,1410 and $1450 \mathrm{~cm}^{-1}$, related to protein groups [21; 22; 24]. In 2006, Hamada et al. found no difference between calcium deposits removed from acute inflammatory stage and from chronic stage [22]. In 2010, Chiou et al. studied mineral components of different ultrasound morphologies of deposits. Three types of IR spectra were found: one for arc or fragmented shapes, one for nodular shape and the last for the cystic shape. These three spectra were closely similar but they found a poorer crystallinity in the "arc/fragmented shapes" group than in the "nodular shape" group. Furthermore, they found different distributions of A- and B-type carbonated apatite according to the US shape. The three crystalline phases were correlated with the US morphology of calcific deposits and with pain intensity. These data suggested different stages of maturation in the calcification process and could be helpful for clinicians to manage patients suffering from calcific tendonitis.

\subsection{Protein composition of calcium deposits}

The organic phase serves as a scaffold for calcific deposits. In bone, for instance, proper crystallization of calcium/phosphate salt needs the presence of collagen fibers. The mineral particles align themselves with their long axes parallel to the fibril axis of the collagen. The apatite crystals appear to deposit first within the holes between the individual collagen molecules and then to spread throughout the matrix. The collagen and associated 
protein play an important role in determining nucleation, growth, and proliferation of these crystals. A better characterization of the protein composition of the calcification matrix could help to better understand the processes involved in the formation of the calcium deposits.

Raman and FTIR spectra analysis show the presence of protein associated with apatite crystals [24]. Osteopontin $(\mathrm{OPN})$ is one among the proteins that have been identified in samples extracted from calcified samples [21]. It is a non-collagenous bone matrix protein associated with bone formation and mineralization. This protein belongs to the SIBLING (small integrin-binding ligand N-linked glycoprotein). The SIBLING proteins are principally expressed in bone and dentin and are secreted into the extracellular matrix during osteoid formation and subsequent mineralization. In bone, osteopontin is an inhibitor of mineralization. Addition of OPN to cultures of osteoblast-like cells drastically reduces the amount of mineral formation [25]. Osteopontin was detected by immunohistochemistry only in cells adjacent to the calcified area and nor in normal tendons neither in cells away from the calcific deposit [26]. OPN is a substrate for the enzyme transglutaminase 2 (TG2), which catalyzes inter- and intramolecular cross-linking affecting the biological activity of the protein. Tissue transglutaminase 2 (tTG2) as also shown to be overexpressed in calcific area [27]. In vascular calcification process, OPN was identified as a potent inhibitor of crystal growth. Hunter et al. showed that VSMCs (vascular smooth muscle cells) derived from OPN-null mice exhibited higher levels of calcification than those from wild-type animals. These data suggest that the abundance of OPN at sites of ectopic vascular calcifications reflects upregulation of the protein in response to crystal formation [25].

Bone Morphogenic Protein-2 (BMP-2) was also proposed as a regulator of tendinous calcification in in vitro studies. Indeed, BMP-2 was able to increase the osteogenic differentiation of tendon-derived stem cells [28]. However, Oliva et al. performed a screening by RT-PCR of genes involved in tissue remodeling and bone development in biopsies from calcified and non-calcified tendon areas [27]. They did not detect any increase of BMP-2 expression but showed a significant decrease of BMP-4 and BMP-6. Osteonectin, expressed in vascular calcification and identified as a procalcifying factor [29], was not increased in calcified areas.

Finally, Grases et al. [21] suggested that phytate could have a role in the development of tendinous calcium deposits. The main sources of phytate in the daily diet are cereals and legumes. In this study, they found a significantly lower urinary phytate concentration in patients with CT than in healthy individuals. Phytate is considered as an inhibitor of hydroxyapatite crystallization and a phytin-enriched diet was able to reduce soft 
tissue calcification in an animal model [30]. Phytate concentrations in blood and tissues are correlated with those in urine, suggesting that these patients have a tissue deficit in this crystallization inhibitor.

To summarize the first part of this review (Figure 2), formation of the calcific deposits appears to be linked to chondrocyte-like cells. Their origin and pro-mineralizing properties remain to be clarified. The calcium deposits contain poorly crystalline carbonated apatite associated with protein. Among these proteins, only osteopontin has been consistently identified and additional studies are necessary to characterize the other proteins present in the calcific deposits.

\section{Resorption of the calcium deposits}

Natural historical course of calcific tendonitis can end by an acute phase associated with severe pain leading to the resorption of the calcific deposit. Factors leading to this phase are still unknown. In the chronic phase, amorphous calcific deposits are surrounded by a fibrocartilaginous tissue without inflammatory cells or vessels and thus can be hidden from the immune cells (personal non published observation). Fragmentation of the calcification or even bursal steroids injection can lead to its disappearance due to the disruption of the fibrous tissue and activation of a local inflammation. During resorption, patients consult for severe pain but the lower prevalence of $\mathrm{CT}$ in the elderly than in the population between 30 and 60 suggests that asymptomatic spontaneous resolution could exist.

\subsection{Initiation of the resorption}

Histological studies of calcific tendonitis retrieved during surgery have shown macrophages and multinucleated cells around broken-up calcium deposits, often accompanied by capillaries or thin-walled vascular channels. These cells have phagocytic capacities and might be responsible for the initiation of the resorption [8; 11]. Macrophages located within mineralized regions of tissue were seen to contain mineral [11]. Furthermore, the multinucleated giant osteoclast-like cells expressed TRAP and Cathepsin K both involved in bone resorption [31]. They are also positive for osteopontin [26]. In mineralized tissues, OPN has an important role in osteoclast 
function. Osteoclasts deficient in OPN do not migrate and are unable to resorb bone [32]. We can assume that OPN could have a similar role in osteoclast-like cells observed around calcium deposits.

Then, diffusion of apatite crystals from the calcification into the subacromial bursa results in severe pain and restriction of movement. The factors that trigger this phase remain unknown.

We will discuss below the mechanisms by which apatite crystals can induce an inflammatory reaction leading to the resorption of the calcification (Figure 3).

\subsection{Pro-inflammatory effects of apatite crystals}

\subsubsection{In vivo pro-inflammatory effects of apatite crystals}

The air pouch model is the most frequent animal model used to explore the inflammatory response induced by crystals. This model has been more largely used to explore monosodium urate monohydrate crystal-induced inflammation. The model has been first described in 1981 by Edwards [33]. Mechanical disruption of the subcutaneous connective tissue in rats or mice by the repeated injection of air results in a cavity with a lining structure having many of the features of synovial membrane. This structure closely resembling synovium is formed after 6 days and provides a convenient model for studying the behavior of synovial lining tissue under a wide variety of easily administered stimuli.

Injection of apatite crystals in air pouch induces a local inflammation with massive cell infiltration throughout the pouch cavity and the membrane lining, accompanied by swelling of the surrounding tissues and vascular dilation $[34 ; 35]$. The exudate and the pouch lining are rich in polymorphonuclear cells and mononuclear phagocytic cells $[34 ; 36]$. The inflammatory response is yet present 6 hours after crystals injection, maximal at $24 \mathrm{~h}$ and spontaneously decreases at 48h [36]. In the exudates, IL-1 $\beta$, IL-6 and IL-18 are secreted in significant amounts. The inflammatory response depends on inflammasome. Indeed, apatite-induced neutrophil recruitment and cytokine production were abrogated in mice lacking NLRP3, ASC or caspase-1 such as leukocyte ingress and swelling of the synovium-like membrane [35]. Finally, TNF $\alpha$ was not significantly increased in the exudate 
after apatite injection [37]. Of note, all these studies have been performed with synthetic hydroxyapatite and the effect of patients carbonated form might induce a different response.

\subsubsection{In vitro effects of apatite crystal on cells}

To decipher the cellular mechanisms leading to the inflammatory response, these experiments have been pursued in vitro. Several authors have studied the impact of apatite crystals on the release of major pro-inflammatory cytokines (IL-1 $\beta$, TNF, IL-6) by monocytes-macrophages. In the oldest studies, hydroxyapatite-stimulated human monocytes inconstantly release IL-1 3 [38-41]. Indeed, it was more recently highlighted that priming is essential for crystal induced IL-1 $\beta$ secretion. This induced IL-1 $\beta$ release is caspase-1 and NLRP3 dependent [42]. Apatite crystals can also increase IL-6 production by human monocytes in vitro with a dose dependent effect [39]. Finally, Di Giovine et al. showed that human blood mononuclear cells treated with apatite crystals could release significant amounts of TNF but this was not constant and appeared to be related to the individual donor [43].

Concerning macrophages, apatite crystals do not stimulate TNF- $\alpha$ secretion even after LPS-priming [35; 44]. However, they stimulate high secretion of IL-1 $\beta$ and IL-18 when using murine macrophages. As for monocytes, LPS-priming is essential to induce IL- $1 \beta$ production. Using peritoneal macrophages derived from NLRP3, ASC, and caspase- 1 deficient mice, HA-induced IL-1 $\beta$ and IL-18 secretion was markedly reduced, highlighting the critical role of the NLRP3 inflammasome in this response [35]. Interestingly, the same study has shown that different physical parameters of crystals exhibit different capacities to induce the inflammasome activation in vitro. Thus, needle-shaped crystals are the most effective to induce an inflammatory response [35]. Cunningham et al. showed that apatite crystals can also activate a signaling pathway leading to the induction of S100A8, identified as an endogenous activator of TLR-4, which can in turn feedback on cells to drive pro-IL-1 $\beta$ production [44]. Finally, high concentrations of prostaglandin E2 were found in the supernatants of peritoneal mouse macrophages stimulated by apatite crystals [45].

Other cells from the synovial tissue could be involved in the production of pro-inflammatory factors after stimulation by crystals. Thus, hydroxyapatite crystals were able to induce IL-6 production by human synoviocytes in vitro. Conversely, IL-1 was not detectable in these cells [39]. 
Overall, the study of mechanisms involved in apatite-induced inflammation showed the crucial role of IL-1 $\beta$, produced after activation of the NLRP3 inflammasome pathway as observed with other in vitro crystals-induced response (monosodium urate or calcium pyrophosphate for instance). Priming of the cells by a first signal is also essential to induce a cellular response. Treatment targeting IL-1 (anakinra) has been evaluated to treat patients with acute refractory pain associated with calcification resorption [46].

\subsection{Tendon healing}

After the disappearance of the deposits, we do not observe tendon sequela [47]. On surgical samples, Uhthoff $e t$ al, observed small areas representing the process of repair. They observed different patterns: granulation tissue with young fibroblasts and newly formed capillaries and also, well-formed scars with maturing fibroblasts. In these areas, newly formed collagen fibrils were detected [12].

\section{Conclusion}

Mechanisms involved in the deposition of calcium in tendons are complex and not yet fully understood. Histological analysis of calcific tendonitis allowed the characterization of chondrocyte-like cells surrounding an amorphous crystal deposit. However, the origin of these cells and the cellular mechanisms involved in their mineralization capacities needs to be further explored. Their expression of alkaline phosphatase and the presence of matrix vesicles are controversial in the literature. Calcific deposits are composed of poorly crystallized carbonate apatite that is linked to an organic phase made of different protein. Osteopontin has been shown to be expressed in the organic phase but other protein need to be identified to better understand the mechanisms involved in the formative phase. The inflammation induced by the crystals and leading to their disappearance involved osteoclast-like multinucleated giant cells and cytokines from the IL-1 family such as IL-1 $\beta$ and IL-18. The NLRP3 inflammasome seems to have a critical role in the resorption. The factors involved in the occurrence of the resolution phase and the different steps leading from the resorption of the calcium deposit to the tendon healing also need to be better characterized. 
The authors declare that they have no competing interest. 


\section{REFERENCES}

[1] Friedman MS. Calcified tendinitis of the shoulder. Am J Surg. 1957;94(1):56-61.

[2] Harmon PH. Methods and results in the treatment of 2,580 painful shoulders, with special reference to calcific tendinitis and the frozen shoulder. Am J Surg. 1958 ;95(4):527-44.

[3] Farin PU, Jaroma H. Sonographic findings of rotator cuff calcifications. J Ultrasound Med. 1995;14(1):7-14.

[4] Louwerens JK, Sierevelt IN, van Hove RP, van den Bekerom MP, van Noort A. Prevalence of calcific deposits within the rotator cuff tendons in adults with and without subacromial pain syndrome: clinical and radiologic analysis of 1219 patients. J Shoulder Elbow Surg. 2015 ;24(10):1588-93.

[5] McLaughlin HL. Lesions of the Musculotendinous Cuff of the Shoulder: III. Observations on the Pathology, Course and Treatment of Calcific Deposits. Ann Surg. 1946;124(2):354-62.

[6] Speed CA, Hazleman BL. Calcific tendinitis of the shoulder. N Engl J Med. 1999 May 20;340(20):1582-4.

[7] Le Goff B, Berthelot JM, Guillot P, Glémarec J, Maugars Y. Assessment of calcific tendonitis of rotator cuff by ultrasonography: comparison between symptomatic and asymptomatic shoulders. Joint Bone Spine. 2010;77(3):258-63.

[8] Uhthoff HK. Calcifying tendinitis, an active cell-mediated calcification. Virchows Arch A PatholAnatHistol. $1975 ; 366(1): 51-8$.

[9] Kannus P. Structure of the tendon connective tissue. Scand J Med Sci Sports. 2000 ;10(6):312-20.

[10] McKendry RJ, Uhthoff HK, Sarkar K, Hyslop PS. Calcifying tendinitis of the shoulder: prognostic value of clinical, histologic, and radiologic features in 57 surgically treated cases. J Rheumatol. 1982;9(1):75-80.

[11] Archer RS, Bayley JI, Archer CW, Ali SY. Cell and matrix changes associated with pathological calcification of the human rotator cuff tendons. J Anat. 1993 ;182 ( Pt 1):1-11.

[12] Uhthoff HK, Loehr JW. Calcific Tendinopathy of the Rotator Cuff: Pathogenesis, Diagnosis, and Management. J Am AcadOrthop Surg. 1997;5(4):183-191. 
[13] Benjamin M, Ralphs JR. Fibrocartilage in tendons and ligaments--an adaptation to compressive load. J Anat. 1998;193 ( Pt 4):481-94.

[14] Archambault JM, Jelinsky SA, Lake SP, Hill AA, Glaser DL, Soslowsky LJ. Rat supraspinatus tendon expresses cartilage markers with overuse. J Orthop Res. 2007 ;25(5):617-24.

[15] Rees JD, Wilson AM, Wolman RL. Current concepts in the management of tendon disorders. Rheumatology (Oxford) 2006; 45 (5): 508-521.

[16] Bi Y, Ehirchiou D, Kilts TM, Inkson CA, et al. Identification of tendon stem/progenitor cells and the role of the extracellular matrix in their niche. Nat Med. 2007 ;13(10):1219-27.

[17] Zhang J, Wang JH. Characterization of differential properties of rabbit tendon stem cells and tenocytes. BMC MusculoskeletDisord. $2010 ; 11: 10$.

[18] Golub EE. Biomineralization and matrix vesicles in biology and pathology. Semin Immunopathol. 2011 ;33(5):409-17.

[19] Boskey AL, Bullough PG, Vigorita V, Di Carlo E. Calcium-acidic phospholipid-phosphate complexes in human hydroxyapatite-containing pathologic deposits. Am J Pathol. 1988;133(1):22-9.

[20] Raggio CL, Boyan BD, Boskey AL. In vivo hydroxyapatite formation induced by lipids. J Bone Miner Res. 1986;1(5):409-15.

[21] Grases F, Muntaner-Gimbernat L, Vilchez-Mira M, et al. Characterization of deposits in patients with calcific tendinopathy of the supraspinatus. Role of phytate and osteopontin. J Orthop Res. 2015;33(4):475-82.

[22] Hamada J, Tamai K, Ono W, Saotome K. Does the nature of deposited basic calcium phosphate crystals determine clinical course in calcific periarthritis of the shoulder? J Rheumatol. 2006;33(2):326-32.

[23] Gärtner J, Simons B. Analysis of calcific deposits in calcifying tendinitis. Clin Orthop Relat Res. 1990;(254):111-20.

[24] Chiou HJ, Hung SC, Lin SY, Wei YS, Li MJ. Correlations among mineral components, progressive calcification process and clinical symptoms of calcific tendonitis. Rheumatology (Oxford). 2010;49(3):548-55. 
[25] Hunter GK. Role of osteopontin in modulation of hydroxyapatite formation. Calcif Tissue Int 2013;93:34854.

[26] Takeuchi E, Sugamoto K, Nakase T, et al. Localization and expression of osteopontin in the rotator cuff tendons in patients with calcifying tendinitis. Virchows Arch. 2001;438(6):612-7.

[27] Oliva F, Barisani D, Grasso A, Maffulli N. Gene expression analysis in calcific tendinopathy of the rotator cuff. Eur Cell Mater. 2011;21:548-57.

[28] Rui YF, Lui PP, Ni M, Chan LS, Lee YW, Chan KM. Mechanical loading increased BMP-2 expression which promoted osteogenic differentiation of tendon-derived stem cells. J Orthop Res. 2011;29(3):390-6.

[29] Ciceri P, Elli F, Cappelletti L, et al. Osteonectin (SPARC) Expression in Vascular Calcification: In Vitro and Ex Vivo Studies. Calcif Tissue Int. 2016 ;99(5):472-480.

[30] Grases F, Prieto RM, Sanchis P, Saus C, De Francisco T. Role of phytate and osteopontin in the mechanism of soft tissue calcification. J Nephrol. 2008 ;21(5):768-75.

[31] Nakase T, Takeuchi E, Sugamoto K, et al. Involvement of multinucleated giant cells synthesizing cathepsin $\mathrm{K}$ in calcified tendinitis of the rotator cuff tendons. Rheumatology (Oxford). 2000 ;39(10):1074-7.

[32] Standal T, Borset M, Sundan A. Role of osteopontin in adhesion, migration, cell survival and bone remodeling. Exp Oncol. 2004 ;26(3):179-84.

[33] Edwards JC, Sedgwick AD, Willoughby DA. The formation of a structure with the features of synovial lining by subcutaneous injection of air: an in vivo tissue culture system. J Pathol. $1981 ; 134(2): 147-56$.

[34] Kowanko IC, Gordon TP, Rozenbilds MA, Brooks PM, Roberts-Thomson PJ. The subcutaneous air pouch model of synovium and the inflammatory response to heat aggregated gammaglobulin. Agents Actions. 1986 ;18(3-4):421-8.

[35] Jin C, Frayssinet P, Pelker R, et al. NLRP3 inflammasome plays a critical role in the pathogenesis of hydroxyapatite-associated arthropathy. Proc Natl AcadSci U S A. 2011 ;108(36):14867-72.

[36] Prudhommeaux F, Schiltz C, Lioté F, et al. Variation in the inflammatory properties of basic calcium phosphate crystals according to crystal type. Arthritis Rheum. 1996 ;39(8):1319-26. 
[37] Watanabe W, Baker DG, Schumacher HR Jr. Comparison of the acute inflammation induced by calcium pyrophosphate dihydrate, apatite and mixed crystals in the rat air pouch model of a synovial space. J Rheumatol. $1992 ; 19(9): 1453-7$.

[38] Dayer JM, Evêquoz V, Zavadil-Grob C, et al. Effect of synthetic calcium pyrophosphate and hydroxyapatite crystals on the interaction of human blood mononuclear cells with chondrocytes, synovial cells, and fibroblasts. Arthritis Rheum. 1987 ;30(12):1372-81.

[39] Guerne PA, Terkeltaub R, Zuraw B, Lotz M. Inflammatory microcrystals stimulate interleukin-6 production and secretion by human monocytes and synoviocytes. Arthritis Rheum. $1989 ; 32(11): 1443-52$

[40] Di Giovine FS, Malawista SE, Nuki G, Duff GW. Interleukin 1 (IL 1) as a mediator of crystal arthritis. Stimulation of $\mathrm{T}$ cell and synovial fibroblast mitogenesis by urate crystal-induced IL 1. J Immunol. 1987 ;138(10):3213-8.

[41] Di Giovine FS, Symons JA, Duff GW. Kinetics of IL1 beta mRNA and protein accumulation in human mononuclear cells. Immunol Lett. 1991 ;29(3):211-8.

[42] Pazár B, Ea HK, Narayan S, et al. Basic calcium phosphate crystals induce monocyte/macrophage IL-1 $\beta$ secretion through the NLRP3 inflammasome in vitro. J Immunol. 2011 ;186(4):2495-502.

[43] Di Giovine FS, Malawista SE, Thornton E, Duff GW. Urate crystals stimulate production of tumor necrosis factor alpha from human blood monocytes and synovial cells. Cytokine mRNA and protein kinetics, and cellular distribution.J Clin Invest. 1991 ;87(4):1375-81.

[44] Cunningham CC, Mills E, Mielke LA, et al. Osteoarthritis-associated basic calcium phosphate crystals induce pro-inflammatory cytokines and damage-associated molecules via activation of Syk and PI3 kinase. ClinImmunol. $2012 ; 144(3): 228-36$.

[45] Alwan WH, Dieppe PA, Elson CJ, Bradfield JW. Hydroxyapatite and urate crystal induced cytokine release by macrophages. Ann Rheum Dis. 1989 ;48(6):476-82

[46] Zufferey P, So A. A pilot study of IL-1 inhibition in acute calcific periarthritis of the shoulder. Ann Rheum Dis. 2013 ;72(3):465-7. 
[47] Serafini G, Sconfienza LM, Lacelli F, Silvestri E, Aliprandi A, Sardanelli F. Rotator cuff calcific tendonitis: short-term and 10-year outcomes after two-needle us-guided percutaneous treatment--nonrandomized controlled trial. Radiology. 2009 ;252(1):157-64. 


\section{FIGURES}

\section{Figure 1. Hematoxylin and Eosin staining of a calcific tendonitis.}

The calcium deposits appear as amorphous areas located within the tendon fibers and surrounded by a fibrocartilaginous tissue.

Figure 2. Formative phase of the calcific deposits.

Under unknown conditions, cells present in the tendon (tenocytes or tendon stem cells) undergo a chondrocytes metaplasia leading to rounded chondrocytes-like cells. These cells might be able to produce matrix vesicles and express TNAP (Tissue Nonspecific Alkaline Phosphatase) leading to formation of calcium crystals. They also produce an organic phase made of collagen and other matrix protein. The calcific deposit slowly grows until it elicits an inflammatory reaction characterized by the presence of osteoclast like multinucleated giant cells expressing cathepsin K. Ultimately, this reaction will lead to the resorption of the calcification

\section{Figure 3. Mechanisms involved in induction of inflammation by apatite crystal in the subacromial bursa.}

A massive cell infiltration, mainly composed of polymorphonuclear cells and mononuclear phagocytic cells, occurs throughout the pouch cavity and the membrane lining. In response to apatite stimulation, monocytes produce IL-1 $\beta$ and IL- 6 and macrophages secrete IL-1 $\beta$ and IL-18 through the activation of the NLRP3 inflammasome. Apatite crystals also activate a signaling pathway leading to the induction of S100A8, identified as an endogenous activator of TLR-4, which can in turn feedback on cells to drive pro-IL-1 $\beta$ production. Furthermore, macrophages can produce high concentrations of prostaglandin E2 (PGE2). Finally, other cells from the synovial tissue could be involved in the production of pro-inflammatory factors after stimulation by crystals: hydroxyapatite crystals induce IL-6 production by human synoviocytes. 


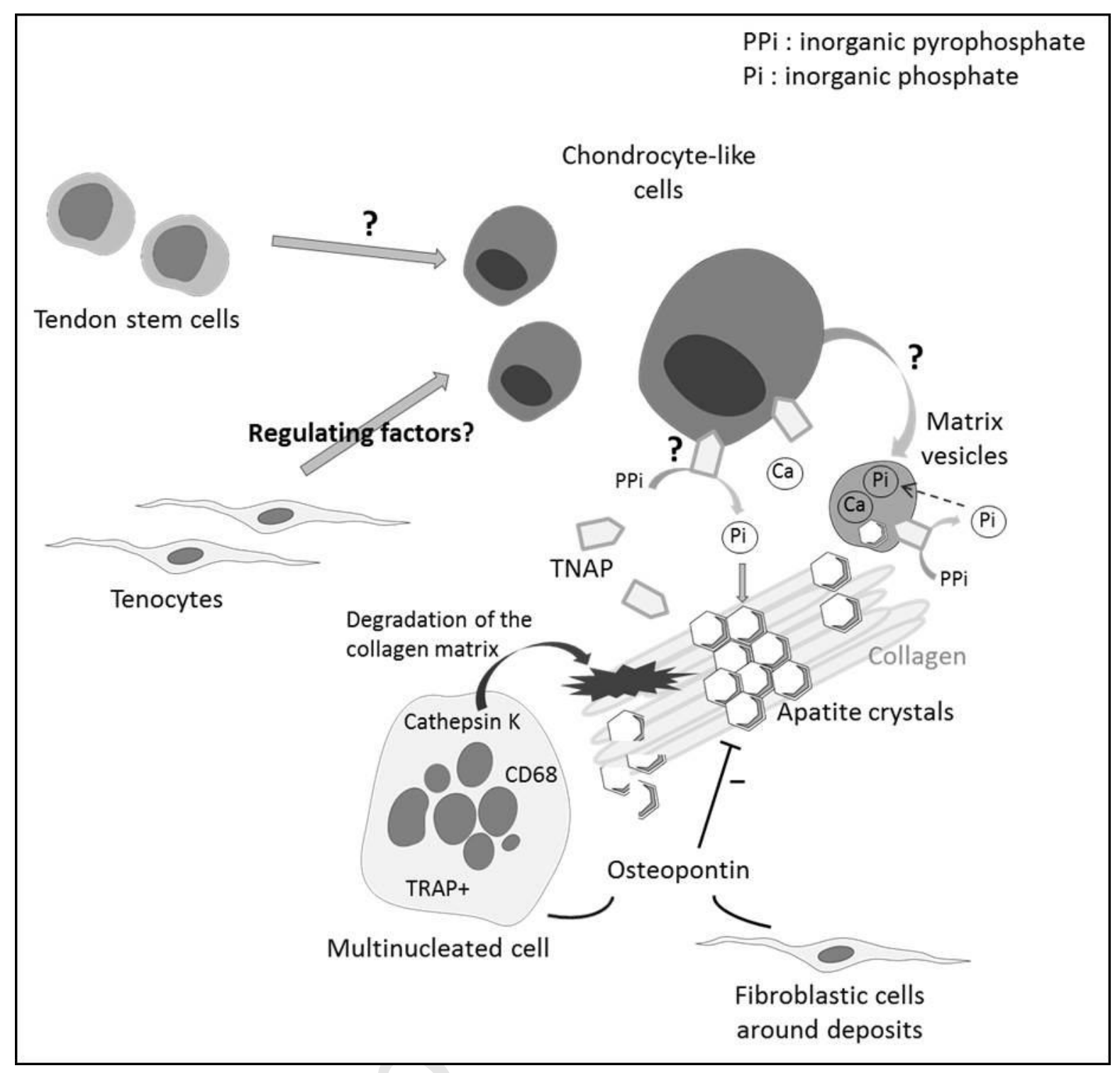




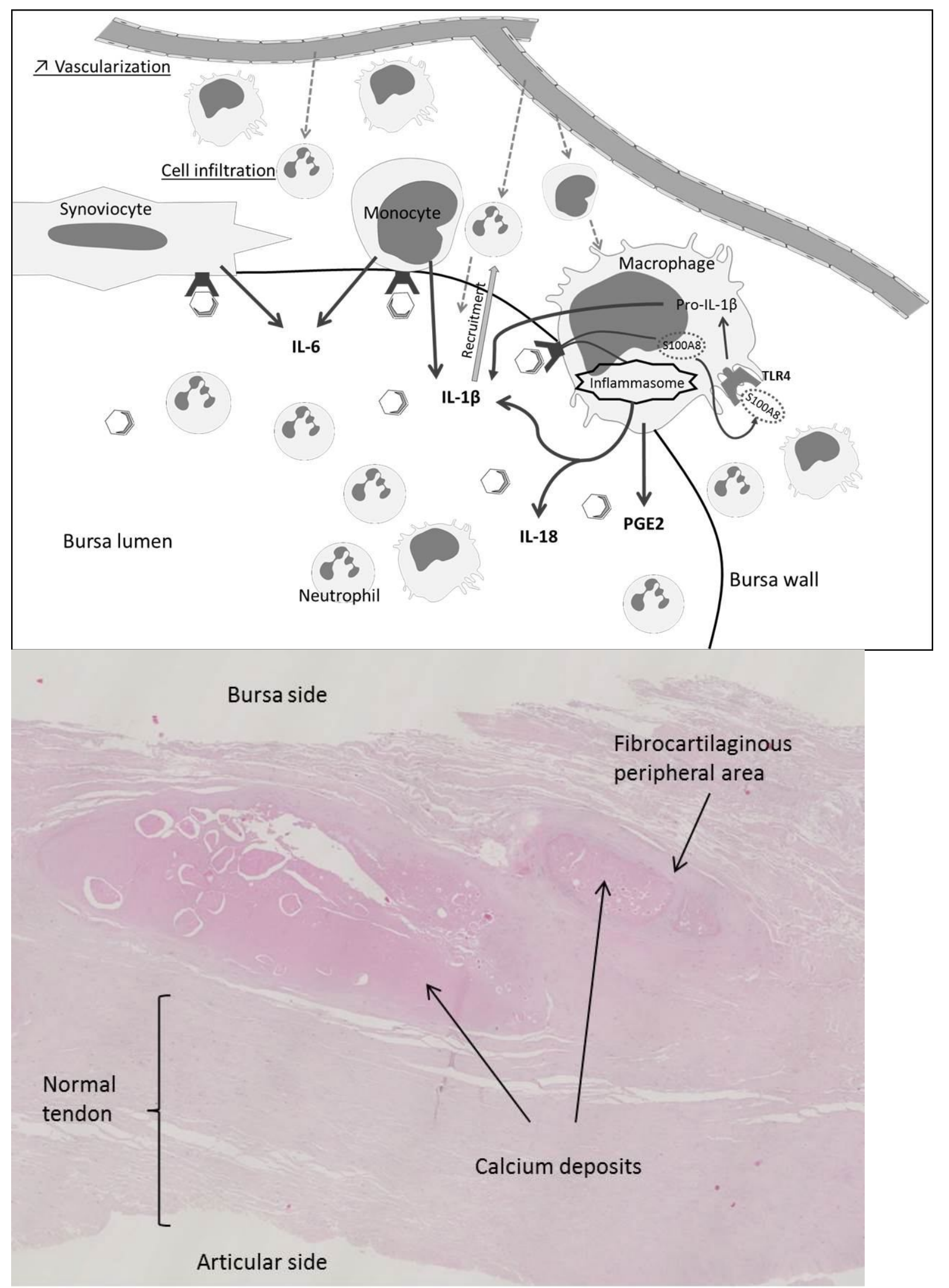

